\title{
Anak Jakarta
}

\section{A sketch of Indonesian youth identity}

\author{
SOLITA SARWONO
}

\begin{abstract}
Anak Jakarta refers to the youth of Jakarta, the trend-setters of the Indonesian youth. This paper gives a sketch of the youth in Jakarta as characterized by their appearance, language, and lifestyle. Information is derived from discussions and personal contact with different groups of youth and parents (adults with children) in Jakarta; literature review, observations, as well as from flashbacks given by the adults, providing a portrait of anak Jakarta since late 1980's. The youth in Jakarta is Western (American) oriented, copying from the mass- and social media, often times conflicting with local norms and parental advices. Anak Jakarta profile includes: youth created slang language, school gang fights (tawuran) and brand minded consumerism. Jakarta youth has become the role model for most youth all over Indonesia, especially Jakarta migrant youth. Family upbringing, social contact, peer group and the media play a crucial role in forming, transforming and disseminating the characteristics anak Jakarta identity.

KEYWORDS

Indonesia, youth, identity, anak Jakarta, lifestyle, slang language, peer group, social media.
\end{abstract}

"Saya (dia) anak Jakarta" meaning I am or (s)he is from Jakarta. This remark is often made referring to someone with the characteristics or attributes typical of the youth living in Jakarta. Sometimes one also hears the remark: "Dia sudah jadi anak Jakarta" ((s)he has already become a Jakarta youth) describing a young person who has come to live in Jakarta and who looks and behaves like an anak Jakarta.

But what exactly are the characteristics or attributes so typical of the youth in Jakarta? How does one acquire these characteristics that become one's identity? What factors influence the formation of this identity and how

SOLITA SARWONO obtained her degree in psychology from the University of Indonesia, public health degree from California State University in San José and her PhD in medical sociology from University of Leiden. She has long years of teaching and research experience at the University of Indonesia before moving to the Netherlands. At present she works as an international consultant in the fields of health, gender, and education. Solita Sarwono may be contacted at: solita.sarwono@gmail.com

(C) 2014 Faculty of Humanities, University of Indonesia 
important is this identity to the youth themselves?

The youth in Jakarta are characterized by specific attributes, such as the way they look (clothing, way of walking and talking), the language they use and the lifestyle they adopt, which may or may not be different from the youth elsewhere. The characteristics of anak Jakarta are sketched in this paper. The sketch presented here is obtained from discussions with different groups of youth and adults (parents) in Jakarta, through direct interviews and via the internet, supported by observations and personal contacts with the youth. A retrospective study compares the portrait of the youth of today and the youth from the past. Adult respondents were requested to provide flashbacks on their experience as the Jakarta youth in the past, namely the youth since the 1980 's. This paper may inspire further discussions and stimulate further study of the youth identity in Indonesia.

\section{YOUTH AND IDENTITY}

Youth is a stage of life every individual experiences: a period characterized by spontaneous, adventurous, non-conservative, changeable, and rebellious acts. If childhood means acceptance, and adulthood means conservatism, youth means rebelliousness (Heaven and Tubridy 2003: 149). Youth subcultures are seen as implicitly rebellious (especially among the younger youth), stemming from the desire to reject the generation that went before them. When a person has reached maturity (psychologically and socially), (s)he tends to conform to social norms and habits, to be more settled, and therefore have reduced the characteristics of youth. Some people stay longer in their youth period than others, meaning they still behave like a youth when their peers have become mature in age and behaviour.

The term youth implies a broad concept and is used in diverse disciplines namely anthropology, sociology, psychology, pedagogy, medicine, law, and economy. Each discipline determines its own age bracket to define the term youth (Sarwono 1989). Despite existing variation, it is generally agreed that youth starts with puberty and ends when the person has reached young adulthood. When one reaches maturity, one is no longer categorized as a youth. The Oxford American Dictionary (Ehrlich et al. 1986: 1086) defines youth as: "the period between childhood and maturity, characterized by a vigour or lack of experience; or young people collectively". The main aspect distinguishing youth from adults is the degree of responsibility a person accepts.

There remains, however, the debate whether a person's age is the most important factor to indicate the period of youth. In Indonesian context, a woman aged 20, for instance, is considered socially to be mature/adult if she is married and has child(ren). On the other hand, there are organizations especially for young people that accept men (and women) up to 40 years of age, married or single, as their members. For example: kumpulan pemuda (youth group) at neighbourhood or village level, the KNPI (Komite Nasional Pemuda Indonesia 'Indonesian national committee of youth'), and HIPMI (Himpunan Pengusaha Muda Indonesia 'Indonesian association of young 
business people'). In my view, Indonesians popularly use the term youth (pemuda) to refer to young people aged 11 to 30 or 40 years. The adolescent group (aged 11 to 19 years) is addressed as remaja.

This paper uses the term youth in a broad and general sense. It refers to young people, from teenagers to those aged 25, married or single, who still feel young and behave like the youth.

Indonesian youth, especially in the cities, are confronted with the symbols of a variety of identities. Aspects from foreign cultures are easily integrated, replacing century old local traditions. The youth are susceptible to new ideas, norms, values, and habits/behaviour from other cultures. The youth are perceived as that part of society most likely to engage in processes of cultural borrowing that are disruptive of the reproduction of traditional cultural practices, varying from modes of dress to language and ideologies. This has been summarized beautifully by Heaven and Tubridy (2003: 149) "Physical characteristics, styles of dress and behaviour, language and communicative accents, and numerous other distinguishing phenomena, act as symbolic triggers in practices of cultural interpretation that attribute collective characteristics to the members of a particular community in a way that locates them within relationships of class, gender, ethnicity, and so forth."

Young people, teenagers in particular, tend to non-critically adopt cultural practices from other places and foreign countries that they see as representing modernity. They do not question the suitability of these practices to their own culture, nor do they want to learn about the essence or the background of those practices. They just copy them as they are. Imitation characterizes youth behaviour. As urban youth has broader access to the world, processes of imitation and borrowing foreign culture go faster among them than among youth living in rural areas. The more cosmopolitan, the faster the youth are influenced by other cultures. Next to adopting foreign cultures, youth also use imitation in search of role models. Popular role models among the youth are famous figures, film stars, rock stars, as well as football players.

Ethnic identity is normally manifested in a variety of aspects, such as cultural traditions and practices (wedding ceremonies and other rituals, music, dance, culinary styles, names, and language). In Jakarta, it is difficult to trace the ethnicity of its inhabitants as cultural aspects have been mixed through inter-ethnic marriages and mixed with foreign cultures. Take for example Javanese youth in Jakarta. The Javanese language, the strongest ethnic identity for this group, is no longer spoken by them. Learning Javanese dance or playing a gamelan instrument hardly interests them. Preparing typical Javanese dishes or snacks may be done by the older generation but not the youth.

The only way to trace the Javanese identity among anak Jakarta is to identify their name, although tracing ethnicity through names has also become more difficult because many Javanese people select modern non-Javanese names, whereas the non-Javanese sometimes use Javanese names, for instance, Liem Sioe Liong, the head of the conglomerate Salim Group, choose a Javanese 
name Sudono Salim for his Indonesian name. Interestingly, when it comes to weddings, Javanese families follow the rituals of the Javanese ceremonies, sometimes very elaborately, much more elaborate than the traditional rituals. Van Leeuwen calls this phenomenon "reinventing traditions" with "fantasy rituals" (Van Leeuwen 1997).

The Javanese wedding rituals performed today are more detailed than the rituals in the 1980's. The day before the wedding, the bride and groom undergo a cleansing ceremony (siraman) in their homes, separately. A number of respected elderly female members of the family and friends bathe the bride with water with flowers in it, purifying and giving her the blessing for the new stage of life. The groom receives the same treatment from respected elderly men, at his parents' home.

The siraman ceremony in the 1980's and 1990's was simple. Nowadays this pre-wedding ceremony is added with the dodol dawet ceremony (with the bride's parents selling to all the guests the Javanese sweet drink/ dessert called dawet) and the reciting of the holy Quran (for Muslim families). The dodol dawet ceremony symbolizes the economic aspect of family life. The guests would purchase the drink and pay it with a token made of a piece of brick, especially made for this event. The more dawet sold, the better the economy of the new couple would be. This wish is strengthened by the prayers recited from the Quran afterwards. The latest fashion of wedding receptions in Jakarta (and other large cities of Indonesia) is the addition of making a set of pre-wedding pictures of the bride and groom and displaying them in the reception hall. The performance of wedding ceremonies in the rural areas of Java, however, remains simple.

A person's identity is always a multi-dimensional compilation of many identities. In the youth development process there is a set of basic personal and social needs, which comprise the needs to feel safe, feel cared for, be valued, be useful and be spiritually grounded, in addition to the need to build skills and competencies, to function and perform in life. To meet their needs, young people tend to seek support from their peers and from the adults. This social support provides them with a sense of safety, security and belonging and it gives them a feeling of self-worth and self-esteem. It is very important for the youth to feel accepted by their peers. They adapt themselves to the group's norms, regardless of parental (dis)agreement, to keep them from getting isolated or excluded by their peers. Their strong need to conform to their peer's norms results in some kind of uniformity among the youth. The looks, language, and lifestyle of members of youth groups are very similar, leaving little room for personal uniqueness.

Beside the need to be perceived as member of the general youth group, individual youth also needs to gain recognition, and to receive responsibility and autonomy from adults. Youth do not want to be treated like children. At the same time, they are reluctant to take full responsibility for their actions. This phenomenon is more common among youth in their teens and young university students. As they get older, they generally adopt more responsibility 
and become less dependent on others.

Now let us look further into some aspects of youth identity, focusing on three major categories, namely the modes of dress, lifestyle, and language.

\section{Modes of dress}

The obvious aspect distinguishing youth from children and adults is their clothing style. Youth wear the latest fashion of clothes, accessories, and hairstyle, which change rapidly following fashion changes in the West. The youth are pioneers in fashion. Indonesian youth tend to follow American fashion, which they copy from movies, video clips, internet, and youth magazines. Indonesian youth magazines present an image of young people dressed in the most recent fashion popular among American youth. Young film stars, pop and rock stars (like Michael Jackson, Justin Bieber) from Hollywood, as well Indonesian film, sinetron, ${ }^{1}$ and pop and rock stars become the idols for the youth in Indonesia, especially in Jakarta.

Boys like a casual look: jeans, a loose shirt, sport shoes, sometimes a baseball cap, and long hair or hairdos imitating those of American youth. Although casual looking, the clothes and accessories are of the latest fashion and carry American, European, or Japanese brands. Tattoos are popular, so is piercing. Some boys can be eccentric in their clothing style or hairdo, as shown by Indonesian Idols contestants. Girls' fashion is more varied. Girls like to wear tight and short clothes (regardless of the shape of the body), sharp pointed shoes, and eye catching accessories, with long straight or very short hair, sometimes dyed reddish or blond, with make-up and perfumes. That is the image of Jakarta female youth in their free time. High school girls wear a school uniform, without make up or dyed hair. Female Muslim youth wear a headscarf (hijab) but also follow Western culture. They wear colourful blouses, shoes, and accessories, with different styles of hijab and long pants, jeans (in different colours) or leggings. Makeup is not tabooed. At school, they wear a long-sleeved white blouse and a long grey or blue skirt, with a white scarf covering their hair.

After finishing school/university and after having found jobs as whitecollar employees, young men are dressed in more formal styles, carrying a briefcase with or without a laptop in it. Young women usually wear a blazer and skirt, shoes with low or high heels, carrying a handbag and a briefcase. Female Muslims are dressed like their peers, with a scarf covering their hair. The high participation of female Muslims in the labour force has driven government offices, banks, and private companies to modify the office uniforms to accommodate the need of their Muslim female employees to dress according to Islamic rules which stipulate the covering of hair, arms, and legs. The uniformity of the outfit is less obvious among those who work in factories, shops, restaurants, or in the informal sector. They are more casually dressed. In their free time, the young people wear jeans and other casual outfits.

1 A sinetron is a television drama series in Indonesia, often starred by young people and very popular among the youth. 
Inseparable from the youth is the cellular phone, popularly known as the $h p$ (handphone). They frequently change their $h p$ when a new model comes on the market, setting the trend for modernity. Smart phones, iPhones, iPads, and Blackberries have become the primary needs to the youth in urban as well as rural areas in Indonesia. The youth like trendy colours and the latest models of cellular phones. They spend many hours and much money chatting, texting, and phoning anywhere, oftentimes ignoring the people (families or friends) around them; an asocial behaviour frequently observed in Indonesia.

Most of the youth are highly brand-conscious. This phenomenon was already noticeable in the 1980's, as becomes clear from the following internet discussions (Yahoo mail group 2010): ${ }^{2}$

- Kita punya salah satu produknya Nike, punya sepatu merek Lotto atau Panther

- Anak-anak cewek pada demen sama produknya Sanrio, Hello Kitty, My Melody, Little Twin Star, etcetera

- Pada bangga banget pake jam digital, biar ALBA juga

- Pada rame-rame beli walkman

- Kalo pake celana jeans, dilipet sampe pas di bawah dengkul, kemeja kotak-kotak enggak dikancingin, sambil nenteng-nenteng tas sekolahan buatan Jaya Giri atau Alpina

- Rambutnya di-punk rock, rada jriwis-jriwis kayak Kim Wilde tapi ada bagian yg panjang dikepang kecil-kecil kayak Adam Ant dijepit/digantungin aksesori kecil-kecil berwarna-warni.

- Pada rame-rame beli skateboard lengkap sama tempurung lutut-sikunya, padahal maen otopet aja nggak becus.

[Nike, Lotto and Panther were popular brands of shoes at that time. The girls liked accessories from Sanrio, Hello Kitty, My Melody and Little Twin Star (mostly Japanese products). Digital watches and walkmans were new products on the market, favourite schoolbags carrying the brands Jaya Giri or Alpina (locally made), jeans pants folded up to the knees combined with unbuttoned checker shirts. A punk-rock hairstyle or a style like that of Kim Wilde, with a small braid on the back, decorated with tiny colourful accessories. They even bought skate boards with knee- and elbow-protectors although they did not have the skill to skateboard.]

Twenty-five years later, these people admitted that they were doing silly things just to follow the fashion.

The youth of the 1990's display a similar casualness:

Rambutnya agak gondrong, dan diberi ciri khas jambul, suka memakai celana jeans, kaos oblong dan kadang kemeja tak dikancingkan, serta sepatu kets (Swastika 2012).

[Long hair with a tuft, blue jeans, t-shirt, and sometimes an unbuttoned shirt, plus sport shoes.]

2 Using the emails (yahoogroup.com), the Jakarta youth of the 1980's have compiled a list of the things they wore and did some twenty-five years ago. 
Youth in Jakarta can immediately recognize youth from other cities by looking at their outfit. Some of them tend to show a condescending attitude toward youth from outside Jakarta, as shown in the following remarks of some teenagers:

"Mereka mau ikut-ikutan, tapi norak. Suka kelebihan. Enggak pantes. Kampungan. Kalau anak Bandung sih masih lumayan, deh. Tapi kalau anak Surabaya, Medan, tampangnya jauh, deh."

[They try to imitate us but in bad taste. They tend to overdo it. It does not suit them. They look village-like (non-cosmopolitan). The youth in Bandung do better than their peers in Surabaya and Medan). $]^{3}$

The condescending remark is also given to the youth who have migrated and are now living in Jakarta. Migrant youth quickly adapt their mode of dress to the Jakarta youth style in order to be accepted by their peers and to obtain social status.

In line with this observation, Van Leeuwen discovered that in developing countries, including Indonesia, modern mass consumption expresses a new social status, in particular for the new rich in these countries. The new rich become a trendsetter to the emerging middle class. As a result, "old" status symbols - such as aristocratic origin - gradually lose their attractiveness and money has become the ultimate aim (Van Leeuwen 1997). The urban middle class, which flourished under the New Order, has not only been receptive of new things but turned indifferent and even contemptuous of the old. Old ways are unfashionable. It is embarrassing to be seen as "behind the times" (Matheson Hooker and Dick 1993).

An important element in motivating the middle class to consume new products is the gengsi 'prestige'. Through gaya gengsi (prestigious lifestyle) the middle class can distinguish itself from the rakyat (the common people, masses, proletariat) and at the same time camouflage its difference from the elite. Characteristic of gengsi is that it represents "participation in the modern era" (Sastramidjaja 2000), with a self-interpreted meaning attached to the word "modern".

The youth's eagerness to try and use something new and modern and their brand-mindedness has triggered and boosted the production of imitation goods, falsifying the original trademarks. Jeans, shoes, bags, watches, clothes with American or European brands and Japanese electronic gadgets are available on the market at very low prices. These products are imported from China or Taiwan or made locally. Presumably, the youth's consumptive behaviour has helped facilitating Indonesia's economy.

The youth identity of those in their teens and those in their twenties differs from that of other age groups. To be a youth is to be distinguished from the

3 It is interesting to note that the youth perceive geography as a factor playing a role in the dissemination of youth clothing style. The closer to Jakarta, the better up-to-date are the youth. 
remainder of the population not just by age, but also by youth-specific cultural pursuits. "The youth typically consume cultural phenomena and assume styles of behaviour and dress that are different from the comparable habits of children and adults", according to Heaven and Tubridy (2003: 149). This profile, along with age, is the most visible and obvious criterion of youth identity as it is currently displayed in Western cultures. This consumptive behaviour makes the youth an easy target for marketing. Western youth are bombarded, throughout their day-to-day life, by advertisements through the internet, social media, and other media that invite them to seek happiness through the accumulation of wealth and commodities. Such a phenomenon may also be observed among the youth in developing countries, Indonesian youth included. The youth feel compelled to adapt to the dominant youth culture. The failure to properly participate in the dominant youth culture can result in social exclusion and alienation.

\section{Lifestyle}

The youth are strongly attracted to modernity and new things. They are open to innovations, new ideas, norms, and everything else symbolizing modern life. The key words describing the youth subculture are modernity, change, informal style, freedom, courage, rebellion, and peers. Lifestyle has increasingly gained significance as a mark of social rank. Sometimes it even serves as a more important criterion of social rank than socio-economic criteria. Lifestyles are not determined by position within a rural - urban continuum, rather they reflect the socio-economic characteristics of the population (Stöve 2001: 2)

Youth lifestyle focuses on image, namely the physical appearance and the style of doing things. Urban youth, especially anak Jakarta, try to constantly improve their image (Swastika 2012). They try to keep up with latest fashion and the newest developments in communication technology. The youth tend to ignore or even reject tradition as it symbolizes rigidity, non-modernity if not backwardness. Modernity gives prestigious status, whereas tradition is considered out-dated (kuno), indicating less/lower status.

As Gerke pointed out, investing energy and money in their outfits and wearing "brand names" is part of the modern Indonesian youth. Even the act of making a purchase becomes part of a group experience of lifestyle shopping and selecting the place for consumption where people meet, display themselves, communicate and interact (Gerke 1995; Van Leeuwen 1997; Ansori 2009). On-line shopping is in fashion nowadays. But shopping in malls provides the opportunity to see-and-be-seen. Beside shopping malls (there are over 100 malls in the Jakarta area), the favourite hang-around places for the youth are American hamburger and pizza restaurants, cafés, play stations, amusement centres, and parks. Recently there is a tendency for the youth to eat out in simple eating-places serving local food or barbeques. Frequent visits of a group of youth will attract others, making the food stalls a social meeting place for the youth. 
The desire to enjoy life and to go out with the peers is also noted in the lifestyle of the 1980's Jakarta youth as sketched by a number of adults by means of flashback reflection (Lapanpuluhan 2006):

- Kalo hari minggu nonton "Little house on the prairie".

- Masih hapal nama tokoh2 di film si Unyil.

- Tiap acara lebaran di TVRI, yang ditunggu-tunggu adalah operet Papiko-nya Titik Puspa.

- Demen ama drama "Losmen", "Rumah masa depan".

- Pernah nongkrongin video rental untuk dapetin episode terbaru serial Voltus atau Goshogun.

- Gandrung sama grup Chaseiro-nya Chandra Darusman and PSP (Pancaran Sinar Petromax), grup dangdut anak-anak UI.

- Saben taon kudu nyari tiket Guruh \& Swara Mahardikka-nya.

- Gara2 John Tralala jadi saban pesta kudu nyewa peralatan disko.

- Waktu SD, harus udah pernah makan di KFC. Aduh, konsumtif sekali.

- Dulu belum ada mall, jadi jalan-jalannya di plaza seperti di Ratu Plaza, trus, bangga banget kalau hari Senin bisa cerita ketemen-temen habis belanja sama ortu di Gajah Mada Plaza.

- Pernah ikut-ikutan break dance dan maen sepatu roda.

[The favourite television programs for the youth of the eighties are the Little house on the prairie, puppet show Unyil, lebaran musical by Papiko lead by Titik Puspa and the series Losmen and Rumah masa depan. They rented (Japanese animation) video films Voltus and Goshogun. They liked Indonesian music groups Chandra Darusman, PSP and the dangdut group from the University of Indonesia students and enjoyed the musical and dance shows by Swara Mahardika lead by Guruh. On the other hand, they also did break dance, partying with rental disco equipment and roller-skating. They went to Kentucky Fried Chicken. Hanging around at shopping plazas was also a common thing to do, the experience can be proudly shared as a show off to their school friends.]

Comparing the anak Jakarta of the 1980's, 1990's, and later, there is a similar pattern in their lifestyle despite the different variation and availability of facilities and technologies. The youth are consumptive, relaxed, informal, enjoy hanging out in shopping centres, and like showing off. The preference of the earlier youth for Indonesian entertainments may result from the lack of access to the international world. But the Western influence is evident (disco, break dance, roller-skating, Kentucky Fried Chicken).

Nowadays anak Jakarta live western lifestyle and use hi-tech equipment. Internet, social media, emails, chatting, mobile phones, computer games, and so on have become primary needs to them. They read youth glossy magazines such as Gadis, Cosmo girl, Seventeen, Hai, and many others. Most of the teenage magazines are aimed at girls. Video, movies, MTV, disco, and rap music fill the youth's daily life. Even Indonesian pop music is strongly influenced by Western pop rock. Other music styles, such as keroncong and dangdut that are popular with the masses, are usually considered low class and kampungan (village like), unless played at the parties of the elite. Jakarta youth adore 
international pop music and culture as it encourages emulation and at the same time recognizes individualism, spontaneity, and a spirit of rebellion (Matheson Hooker and Dick 1993).

Although it is impossible to speak of one youth culture, a common characteristic is the longing for a free lifestyle that is closely associated with the urban life (Stöve 2001). Free to speak and to do what one likes, to choose friends, to go out, partying, dancing and staying in disco's all night long, some of them are engaged in teenage prostitution, riding cars along the streets of Jakarta, and blowing trumpets on New Year's eve, smoking, using marijuana and other narcotics and drugs, all of that symbolizes free lifestyle, which the youth see as modern life. This is a form of rebellion against tradition and established norms. Hence it is little wonder that in exercising this freedom the youth often come in conflict with parents and other authority-representing adults. The youth do not like to follow rules in the family, at school, or in society at large, which reflect adults' control.

Freedom includes having free time to do whatever one fancies, which often serves no purpose other than being with peers and being away from personal obligations (doing homework, helping parents at home or at work, etcetera). The desire to have free time drives some youth to cut class and go to shopping malls or to food tents (warung) near the school, sitting, chatting, and smoking cigarettes with their peers. Many parents are unaware of this misbehaviour until they hear about it from teachers. It seems that boys miss classes more often than girls, although the proportion of undisciplined girls is increasing. Boys and girls in school uniform wandering on the streets or in the malls during school time is becoming a more and more common a view in Jakarta.

"Kita pernah ngerasain sekolah setengah hari," say the youth of the 1980's.

[We have spent half day at school.]

"Ngapain kita musti di kelas terus. Ngantuk. Mendingan ngobrol atau jalan-jalan deh. Kalo ketauan guru paling-paling disuruh push up. Pasti deh semua anak SMP atau SMA pernah bolos, paling enggak sekali." This is a remark given by the Jakarta youth of the twenty-first century (personal interview, 20 April 2012).

[What is the use of staying all day in class? I feel sleepy. Chatting or taking a walk is much more fun. If the teacher finds out, he'll do nothing but letting us do the push ups. Guaranteed that every high-school student has ever cut class, at least once.]

Part of the youth characteristics is the need for recognition, especially by their peers. In gaining recognition, male youth often show their power by having physical conflicts with their peers. Getting into a fight increases their macho image, they believe. There is an increasing tendency, however, to have group fights rather than to fight individually. Fights between youth gangs or school students (popularly called tawuran) are becoming more and more common a sight in Jakarta. Oftentimes a simple misunderstanding between two persons 
is blown out of proportion by peer groups and triggers fights. The youth throw stones/rocks, bottles, and vandalize public (sometimes also private) properties in the vicinity of the fights.

In the 1990's youth tawuran scared the people and it became increasingly more radical by 1996 (Tampati 2012). Records at the Jakarta Metropolitant Office show 157 student fights in 1992, in 1994 there were 188 fights with 10 casualties, in 1995194 fights with 15 casualties, whereas in 1998230 fights were recorded in which a total of 15 students and two police agents lost their lives. The following year 37 people died in tawuran. The figures show an increasing trend both in the frequency of the fights and the number of casualties (Zander 2012).

"Aduh, macetnya jalanan. Lagi-lagi tawuran. Heran deh, anak Jakarta kok senengnya tawuran, sih?," said a lady from Bandung who came to Jakarta one day. She complained about the traffic jam caused by tawuran, which she identified as something typical of anak Jakarta (a conversation with a friend in Jakarta, May 2011).

Older youth (early twenties) are often engaged in street demonstrations, protesting against the establishment. The initiators of such protests are usually university students, who mobilize young people from outside campus to join them. These protest actions are better organized than the tawuran of highschool students although they too jam traffic. In the past decade, the people of Jakarta have often been disturbed by youth demonstrations organized by political parties. Taking part in such demonstrations are usually early adult males (20-25 years), many of whom work in the informal sector or are unemployed. The youth join the adults to voice the people's frustrations about the country's conditions. Violence and vandalism are quite often associated with such demonstrations.

Another way to attract attention is making graffiti. It is usually made by male youth. Graffiti for them is an art and they are proud of it. It is even a challenge for them to be able to make graffiti on the places difficult to reach, like on the side of the bridge or on the walls of the houses in the elite area that are usually guarded. Graffiti is an expression of freedom, they say. Vandalism is frequently associated with male youth as well. They vandalize public property, to channelize frustrations and social jealousy. But sometimes the youth destroy objects just for fun or to display their courage and power to their peers. Delinquent youth believe that rules are made to be broken. A negative reaction from the surrounding when catching them on the act, gives the youth an extra "kick", excitement and pride, as admitted by Hamzah (17 years):

"Kite lagi iseng ngelemparin lampu jalanan pake batu, tau-tau ada satpam liwat. Dia teriak dan ngejar kite. Kite kabur deh nyebar kemana-mana, sampe si satpam kebingungan mau nangkep yang mane. He, he, he" (24 August 2011). 
[We were just throwing stones to the street light for fun when a security guard spotted us. He yelled at us and chased us but we ran to all directions so that he did not know which way he had to go to catch us. Ha, ha, ha.]

Included in the concept of modern and prestigious (gengsi) for the youth is to have an education. "Titles, diploma's, degrees, and certificates are symbols, and those who possess the symbols of education are knowledgeable in the same way as those who own the symbols of modernity are modern" (Gerke 1995: 14).

In order to obtain the symbols of education young people of the middle and upper classes are sent by their parents to higher education institutes to obtain the highest diploma available. Some families choose schools and universities with high status, if possible overseas, as diplomas from foreign countries are more prestigious and give better access to employment, although the quality of the university is not always better than the local ones. Others do not even bother to take the trouble to follow the study program to get the diploma. They just buy the diploma. As long as there are universities willing to sell fake diplomas to the rich, the demand will be met.

In an interview with a very wealthy family living in the elite area of Kemang, south Jakarta, the lady of the house said:

"Saya kirimkan semua anak saya sekolah ke Inggris atau Amerika sejak mereka lulus SMP. Soalnya mutu sekolah dan universitas di Indonesia enggak bagus, sih. Lagi pula kalau tidak punya ijazah luar negeri, sulit sekali cari kerja di Jakarta nantinya" (June 2011).

This lady sent all her three children to England or USA to study since they were in high school, because she did not value the quality of education at the Indonesian schools and universities. Moreover, she believed that getting a job in Jakarta would be much more difficult without diplomas from foreign countries.

Another well-to-do family sends the children abroad for a slightly different reason:

“Anak-anak kami sekolah di luar negeri supaya mereka bisa belajar hidup modern. Kalau mereka sudah lulus dan tidak bisa dapat pekerjaan di Indonesia, ya sudah. Mereka bisa cari kerja di luar negeri. Kan diplomanya juga dari sana" (June 2011).

[Our children study abroad to learn about modern lifestyle. After they graduate they will try to find a job in Indonesia. But if they failed they could go abroad to try their luck there, since they already have the diploma from that country.]

The importance of education has driven parents of all economic levels to send their children to school. For the lower and middle classes education is not only important as a status symbol but it is essential for employment. Their limited resources hinder low-income parents in selecting schools and in determining the level of schooling for their children. Lack of financial support often forces youth from low-income families to discontinue their 
education before they could reach the higher education level. Stöve observes that two simultaneous processes took place in Jakarta over the last decades. On the one side, a concentration of capital that is circulating in the city and the emerging of the new "very rich" and a middle class aspiring - at least symbolically - to share in their "cosmopolitan" lifestyle. On the other side, a continuing inflow of migrants trying to make ends meet at the bottom line of the social scale. These processes resulted in a diversity of social-economic standards, status of inhabitancy, ethnicity, and the religious background of its inhabitants (Stöve 2001: 5).

\section{Language}

Jakarta's population is a mosaic of ethnicities, each having its own language. Nevertheless, the young generation born in or having migrated to Jakarta, hardly speaks their native language. At school, they learn the official language, bahasa Indonesia. Unlike in other provinces, the local dialect (bahasa daerah) is not taught in primary schools in Jakarta, perhaps due to the large variety of ethnicities living there. In social life, the youth communicate with each other by mixing the Indonesian language with the local dialect bahasa Betawi, or use the slang language which they learn from the peers. They only use correct Indonesian when speaking to teachers, writing essays and other school assignments.

Language and communicative accents are key attributes shared by members of a particular community. The youth all over the world like to use a slang language, with vocabulary and grammar not conforming to the original language. The youth in Jakarta use bahasa Prokem developed in the 1980's, later bahasa gaul and the most recent is bahasa Alay, that gains popularity in the past few years. Although called bahasa (language) they are more of a dialect than a language. These dialects are more informal, intimate, and less structured than bahasa Indonesia and used to communicate with other youth in privacy, outside the control of adults. By using bahasa Prokem, bahasa gaul, or bahasa Alay young people can have the freedom to share their thoughts and feeling with their peers, without interference from adults.

In bahasa Prokem, constructed by the youth from the Betawi dialect, all the secret terms are created to avoid interference from anyone not speaking the language (Lumintaintang 2000). Some words in bahasa Prokem originate from the terms often used by homosexuals in Jakarta (Swastika 2012). The development of bahasa Prokem that was later disseminated by the youth throughout the country demonstrates the creativity of anak Jakarta. This means of communications, which basically is a secret language with specific codes used by criminals, is not merely a compilation or collection of words. It has grammatical rules. In fact, this youth creation has gained so much importance that a special dictionary for bahasa Prokem was published for the first time in 1988 by Rahardja and Chambert-Loir and renewed in 1990. 
“...Mas Donny yang cucok, terus terang nih, akika jatuh cintrong sama yei. Kalau yei tintra membalas cinta akika, kika mawar bunuh diri di bawah pohon terate deh rasanya. Jadi, yei jangan tolak cinta kika, karena setiap malam mimpi akika cuma berisi yei punya body. Rasanya akika tintra bisa hidup tanpa yei, akika jadi tintra endang makasar, tintra bisa tidur nyenyak, tintra bisa melakukan apa-apa. Wajah Mas Donny selalu terbayangbayang di mata ike, ke mana pun ike pergi" (Sarjana 2009).

[Dear handsome Donny, to tell you the truth, I am falling in love with you. If you do not love me, I feel like killing myself under the lotus tree. So please do not reject my love, because every night I dream of your body. I can't live without you, I lose my appetite, can't sleep well, and can't do anything. Your face, dear Donny, stays always in my mind wherever I go.]

The onset of bahasa Prokem is a social phenomenon that answers the youth's need to get the freedom to express their thoughts and to have privacy in communicating with their peers.

In the 1990's, bahasa gaul started to become popular. Stemming from the language used by transvestites in Jakarta, gradually this dialect became popular among the urban youth too (Lumintaintang 2000). The name shows that this slang language is used for socializing (gaul comes from the word bergaul, 'to socialize'). Most of the vocabulary of bahasa gaul from the Indonesian language but is shortened and altered (dipelesetkan or pelesetan). Also English words are used and altered. The sentences are short but communicative and lively. As it is informal, flexible, lively, short, and communicative, bahasa gaul quickly gained popularity among the youth. Even some adults in Jakarta communicate in bahasa gaul in informal settings (Wisbenbae 2010). Stöve (2001) finds bahasa gaul very suitable for socializing and networking. For this reason, bahasa gaul has been adopted in café circles, among young businessmen, and in advertisements in lifestyle magazines. It is increasingly popular to use bahasa gaul in text messages as it is short and concise. A dictionary for this bahasa gaul has been published (Sahertian 2002). Later it was disseminated through internet. This popular dialect is also called the informal Jakarta dialect (Badudu 1996), replacing the use of the correct Indonesian language. In fact, the youth and young adult who speak Indonesian correctly are often labelled kurang gaul (not much socializing).

Although bahasa gaul is still spoken, around 2010 there came a new youth language, the Alay. The origin of the language is varied. Some words stem from Indonesian being cut and joined to form new words, making it difficult to detect their origin. Others are formed in combination with figures and characters. The Alay is more noticeable in text messages than in verbal conversations. The youth do not always share the same understanding of the meaning of the words. Many cannot explain the meaning of the words they are using. The word alay, for instance, has various interpretations such as: youth with free social contacts; trendy, attention getting youth; or preteenagers showing too much acts; whereas according to the Wikipedia the word comes from anak layangan (kite flyer), describing someone having certain 
physical attributes from spending most of their time outdoors and getting sun-burnt such as reddened hair and skin (Wikipedia 2011). Apparently, the youth do not mind the multi-meaning of the words. They use the words as they understand them. Probably as this slang dialect further develops and is longer in use it will take a clearer form and gain more shared agreement of the meaning of the words.

Still in its infancy, bahasa Alay has spread out to diverse places on Java and other islands, reaching rural and remote areas. The spread is accelerated by the use of social media, which is very popular among the youth. Through the social media, written messages are created and further developed, forming a secret language/code among the users. A dictionary of bahasa Alay has been constructed, is continuously updated and made accessible through Facebook, Twitter, and YouTube. A number of bahasa Alay dictionaries have been compiled by individuals and put in their blogs, inviting the public to add and revise the vocabulary (Wikipedia 2011; Konkzmedia 2012). Some examples of bahasa Alay:

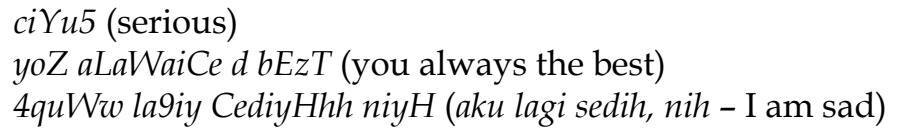

There seems to be several forms/styles of this Alay language shared by groups with different backgrounds in social economic and education levels, as well as from different affiliations. The meaning of certain words/texts can be understood only by members of a particular group, and one may give a condescending or disapproving look to a person using the words/ terms considered as "low class". Compared to the previous youth's slang languages, the variations in bahasa Alay indicate liberalization and a higher degree of freedom and flexibility in the construction and development of this youth language.

The usage of the slang language among the youth, particularly teenagers, has lead to serious concern among schoolteachers, since it tends to hinder the learning of correct bahasa Indonesia and other languages. Despite this concern, it is inevitable that the youth would continue speaking in slang language. Teachers and parents cannot provide 24-hour supervision on the youth.

\section{EXCLUSIVE YOUTH GROUP: ABG}

Within the youth culture in Jakarta in the last decade a sub-culture has emerged and has gained its characteristic as typical anak Jakarta. This sub-culture has been developed by youth aged 11-16, popularly called the Anak Baru Gede or ABG for short which means growing-up teens. Most of these teenagers grow in a world filled with modern technology/gadgets and western lifestyle. Their lifestyle and clothing attire are clearly influenced by Western styles and, like the older youth, the ABG are very brand-minded (Republika 2003). No less than Levi's jeans, Nike, Adidas shoes, as well as Apple, Nokia, Samsung, and 
other famous brands in electronic gadgets are the ABG's favourites.

The boys like to wear over-sized shirts and t-shirts, baggy pants, sport shoes, carrying a backpack, hanging around shopping malls, parks, cafés, or game stations with their peers. The girls wear tight and short blouses or t-shirts, miniskirts, sport shoes or sharp pointed shoes, long straight or very short hair. Like boys, girls enjoy shopping in malls, going to discotheque and café's, and spending hours in play stations. ABG boys and girls seldom go alone, always in groups.

Based on the above description it is easy to assume that the ABG is an exclusive group of middle and upper class families, who can afford to provide them with the luxuries. Wittman (2004) observed that some of these ABG boys and girls have their own credit cards, go to café's and stay overnight in hotels. This ABG phenomenon, however, can also be observed among youth of the lower class, who copy the clothing and other styles of their more wellto-do peers, using lower quality materials. They will settle with duplicates of famous brands, locally made. What matters is appearance. Like the older youth, the ABG group also uses bahasa Alay and bahasa gaul in communicating with their peers (Sarjana 2009; Unnanoche 2010; Havianty 2012).

It is interesting to note that the ABG phenomenon was not observed among the Indonesian youth of earlier periods (the 1980's and 1990's). Does this new phenomenon result from diminishing parental control, rising need for freedom of expression and attention or a tendency for hedonism? Further and deeper studies may help in better understanding the emergence of the ABG phenomenon.

\section{TRANSFORMATION OF YOUTH IDENTITY}

Over the years the profile of anak Jakarta has become the ideal identity for most Indonesian youth for different reasons. Anak Jakarta represents modernity and a cosmopolitan identity. It radiates prestige and status. For migrant youth the possession of an anak Jakarta identity is an essential means to survive in the highly competitive life of the Indonesian capital city. There is a difference in the reasons given by migrant youth from different levels: the youth from the working class see the adjustment to the local norms as a method for survival, whereas the youth from the growing middle class imitate the anak Jakarta style to be socially accepted by the "gangs" or small groups. Below is a portrait of the life of selected migrant youth in Jakarta.

Ami (17), a girl from a small village near Prambanan, came to Jakarta to find work. She was lucky to get a job in a cleaning service company, working at a luxurious apartment building in the centre of Jakarta. Six months after her arrival in Jakarta, her appearance has changed. Her skirts and old clothes from the kampung (hometown) have been replaced by tight jeans, tight $t$-shirts, sport shoes, jacket, and a jeans backpack. Her hair is cut short. When riding in an over-crowded bus, she fits very well with the other youth of Jakarta.

Tri, a boy of 20 from a small village outside Yogyakarta also came to Jakarta to work. He got a job in a factory at the outskirt of Jakarta. After two years in 
Jakarta, the shy and simple looking Tri has become a modern Jakarta youth. His working contract has been extended and his job is secured. Tri always wears blue jeans pants (although not Levi's), a jeans jacket, jogging shoes, his long hair dyed orange-red and he rides a motorcycle, that he bought with a one year credit.

Ami's aunt and Tri's mother, both working as pembantu (domestic help) in Jakarta, disagree with the youngsters' new looks, especially when these youth have to spend much money for it. Their consumption is higher than their purchasing power. Their incomes can barely cover their daily needs. Moreover, they are expected to send home some money to help their parents and siblings. Yet they spend most of their incomes on clothes just to keep up with the appearance of the local youth. But Ami and Tri do not share the worries of the older generation. To both of them to look like anak Jakarta is an essential element to survive in the new environment.

"Kalau tidak bergaya seperti anak Jakarta, nanti saya diejek teman, malah bisa dijambret di bis. Soalnya yang diincer sama copet biasanya orang yang baru datang ke Jakarta," says Ami.

[If I did not look like anak Jakarta my friends would tease me or look down at me. I could even get robbed in the bus, as the pickpockets usually take the new comers as their target.]

Tri's comment: "Di pabrik dan di tempat kos saya, semuanya berpakaian seperti ini. Kalau saya tidak ikut bergaya begini, bagaimana saya bisa naik pangkat? Saya akan diejek sebagai orang kampung terus."

[Everyone at the factory and at the place where I live is dressed like this. If I did not follow the style, how could I get promoted? I would always be teased and looked down as a village boy.]

More migrant youth I interviewed share this opinion. Besides meeting the need for survival, by following the group's dress mode the youth increase their social status (gengsi or prestige). All youth, rich or poor, need to obtain social recognition and do not want to feel excluded from their peers. When Ami, Tri and their fellow migrants return to their village to visit family and relatives, they are proud to hear compliments regarding their new identity: "Sekarang sudah jadi anak Jakarta, ya". (Now you have become anak Jakarta).

Sun and Yun (19 and 17), two sisters from a village near Madiun, East Java, have been working for a few years as baby sitters in Jakarta. At home they are dressed modestly, and when their employers take them out with the children, they wear white dress, a uniform for baby sitters in the urban areas. In their spare time they watch their favourite programs on television, such as sinetron series, dangdut music and dance, and the comedy ketoprak humor.

Through these television programs they learn about the lifestyle of the youth in Jakarta. When these girls return to their village they are dressed in the modern outfit, walk and talk like anak Jakarta. They are proud to be 
identified as anak Jakarta, and their families and relatives admire their newly assumed identity. Sun and Yun also brought gifts to the families and friends at home, gifts that represent modernity, such as t-shirts, jeans, handbags, cookies, candies, etcetera. They want to share the glamour of Jakarta lifestyle.

In order to keep up with the new look and to purchase the gifts, Sun and Yun use all the money they have saved for the entire year and sometimes they borrow money from their employer or fellow employees. When they return to Jakarta they are practically broke, and will have to start saving money anew. Although they have to work hard to earn little money in Jakarta, Sun and Yun are reluctant to return and settle in their home village. They have enjoyed the luxury of life in Jakarta. Why should they exchange that with working in the rice field in their village, which does not have electricity and thus no television?

This phenomenon is not unique of Sun and Yun. It is also common to hundreds of thousands and perhaps millions of poor migrant in Jakarta. They live as scavengers or even beggars on the streets, but once a year, around Idul Fitri (the end of the fasting month Ramadhan) they go home in a modern outfit, carrying bags full of goods and cash for families and friends. These people create an illusion of the wealthy, luxurious and glamorous life they live, which lures other young people in the villages to migrate to Jakarta as well.

Families who have migrated to Jakarta often feel pressured to meet the demand of the youth to adjust to the local lifestyle. The Simamora family, who moved to Jakarta from Berastagi in North Sumatra sketches the situation as follows:

"Di Jakarta ini anak-anak kami yang mulai remaja sering merengek minta dibelikan iniitu. Katanya mau ikut teman-teman mereka, biar tidak ditertawakan. Hidup kami tidak mewah, tapi cukuplah. Tetapi dengan tuntutan anak-anak ini, kocek kami jadi kempes."

[Since their arrival in Jakarta, the teenage youth in the family often ask for various things to adapt to the lifestyle of the Jakarta youth, in order to keep them from being ridiculed or humiliated by their peers. This demand is an extra cost for this middle-class family, reducing the family income/savings].

The Basuki family from Cilacap, a town in Central Java, faces a similar situation:

"Susah Bu, anak-anak kami jadi ketularan remaja Jakarta. Seneng aksi-aksian dan tidak patuh orangtua. Malah mereka jadi suka membantah omongan orangtua. Juga mereka suka main telpon berjam-jam. Membuat PR saja kok liwat telpon. Tanya sama teman. Di Cilacap tidak seperti itu."

[Our children are affected by the Jakarta youth. Showing off and not obeying/ listening to the parents. They even dare to protest or argue with us. They also like to spend hours on the phone. They even consult their peers by phone in doing their homework. The children in Cilacap, do not do that.] 
The interviews indicate that migrant parents do not entirely agree with the new adopted values of the youth in Jakarta but they have little choice than meeting the demand of their children to facilitate the process of adaptation to the new social environment.

The poor in the urban areas feel a strong social pressure to increase their status, showing a lifestyle matching that of the middle and upper classes. This group, especially migrants, would do anything to upgrade their appearance and lifestyle in order not to be called orang kampung or orang udik (both terms refer to people from the rural areas). To achieve this goal the poor spent much money and energy in consumptions, oftentimes beyond their economic means. "Consumption itself has become a symbolic act to demonstrate a lifestyle" (Gerke 1995: 4). For instance, one can find a colour television set in a shaggy shelter in the slum area of Jakarta. It is quite common that the poor (youth and adults) borrow money just to consume goods too luxurious for their socio-economic level. "Culture and economics are mutually constitutive and cannot be understood in isolation. Yet, they are also not reducible to each other" (Ansori 2009: 91).

It is evident that the Indonesian youth have a strong need to adopt and replicate the identity of anak Jakarta. This need might be stronger than the need of the American youth to look, behave and speak like New Yorkers or the eagerness of the Dutch youth to be identified as Amsterdammers. The latter remain trendsetters and innovative but they retain some of characteristics of local cultures, for instance local dialects and styles. Uniformity in youth fashion and behaviour in industrialized countries is less evident. The visible gap in socio-economic and education levels between the youth in Jakarta and the youth in the periphery may explain the strong desire of the Indonesian youth to duplicate anak Jakarta identity.

The examples mentioned above support the observation of Heaven and Tubridy (2003: 155) who stated that the youth in the developing world are attracted, lured or forced into non-traditional ways of being by a great many factors, economic necessity being the most significant, making them alienated from their traditional communities. Such cultural disintegration is the primary cause of problems such as the loss of linguistic, historical, and spiritual tradition and the breakdown of family support structures.

\section{INFLUENCING FACTORS}

One of the basic social needs of the youth is to have a personal as well as group identity. The formation of one's identity is influenced by various factors. To name a few: family education and norms, social contacts, peer group, and the media.

As mentioned earlier, this paper is not based on a thorough study with quantitative measurement. Nevertheless, from the information obtained, assumptions can be made regarding the factors influencing Jakarta youth identity. I will try to give some explanation of the relation between these factors and youth identity. 


\section{A. Family upbringing}

The education and formation of a child's character start at home. From its parents and siblings a child learns and internalizes societal and religious norms and values. The Indonesian family setting usually consists of more than parents and siblings only. Sometimes grand parents, relatives, as well as servants and baby sitters live in the same house. They too play an important role in the formation of a child's personality. Children of middle and upper class families often have more contacts and closer relationship with their caretakers (baby sitter, aunt, or grandmother) than with their biological parents who spend more time outside the house to pursue their career and social life. Parental lack of attention is often substituted with gifts (toys, foods, and money). It is not the mother but the caretaker, who teaches very young children to speak. A child's first language is often the language spoken by the caretakers, which can be their ethnic dialect or slang Indonesian. As the child grows older the parents, particularly the mother, will give more attention to its education. This comprises schooling, religious education as well as training in etiquettes, discipline, social norms, and rules.

In discussions with the parents of Jakarta youth illustrated above, there is an indication that parents do not always approve the youth lifestyle, particularly their consumptive behaviour, although others encourage such a lifestyle to increase the youth's social status, as shown in the example of getting education abroad. Migrant parents tend to have stronger objections to the youth consumptive lifestyle than parents born and raised in Jakarta. What the parents in general share is the disapproval of the youth tendency to rebel and to exercise freedom, showing non-compliance to parental figures. The degree of youth rebelliousness or compliance depends on parental training or upbringing at home.

\section{B. Social contacts}

People are social beings who need social contacts. For the youth social contacts are very important as they provide security, a feeling of belonging and it prevents alienation. Parents can punish the youth by prohibiting them from seeing their friends and taking away their free time by giving them work to do. This type of punishment can have stronger effects on the youth than angry words or physical punishment (push-ups, locking them up in their room, etcetera). But today's youth are not easily cut off from their peers thanks to their telecommunication devices. Through hand-phones and social media they can remain in contact with the outside world. Only when the parents close down all access to telecommunication channels will the youth be socially isolated.

\section{Peer group}

The youth feel very close to their peers. To many youngsters their peers are more important than their parents. The influence of peers on an individual's decision-making is much stronger than their parents' advices, suggestions, or instructions. The youth, especially adolescents, follow their peer group's 
behaviour, norms, and values almost blindly. When given sensible advice by adults (parents, teachers, or older siblings) which contradicts the behaviour or the norms of their peers, they would reject the advice and label it as kuno (old fashioned).

Group solidarity is often used as a reason to exercise power, as manifested in group fights, vandalism, and criminal acts. On the other hand, group solidarity can support and increase group cohesiveness, helping and defending each other. The functioning of youth groups is determined by their (formal and informal) leaders.

Youth often react emotionally, which makes them vulnerable. When a young individual lives among anti-social or delinquent youth, (s)he will likely turn into a person with similar deviant behaviour. Only few young people have the courage to resist peer pressure and bear the consequences of their resistance. How much the peers can affect individual youth depends on the strength of the norms (social, cultural, and religious) and the sense of discipline that have been internalized by the individual before (s)he reaches puberty or adolescence.

\section{Media: mass media and social media}

Youth culture is strongly influenced by the media. The globalization of Western youth culture is done through the media. Examples of modern lifestyle are broadcasted throughout the world via television, internet, as well as social and print media. Films and music from MTV are downloaded and saved, so that everybody can enjoy it for a long time. Youth shows and contests like the American Idols, America Got Talents, and the X-Factor are copied in many countries. The youth in Jakarta copy from the television the lifestyle of Hollywood, Bollywood, or Latin American telenovela film stars, as well as that of the sinetron stars. Through films, sinetron, and the social media the Jakarta youth further disseminate their lifestyle to other youth across the country. It seems that youth films and television series have become quite popular since the beginning of the new millennium, putting the ABG in the lime light.

The globalization of cultures through media is confirmed by Hannerz (1996) who wrote that the media play a part in offering substitute world city spectacles. As the media reach the homes of the world population, hardly anybody can remain ignorant and unconcerned by what is presented in the media. Today, long distance travel, telecommunications and the mass media extend urban influences and options well beyond city boundaries.

Sastramidjaja states that lifestyle-media specifically targeted at the Indonesian youth have succeeded in promoting a sense of belonging to a "specific youth world". "Through MTV, Pepsi-Cola commercials, and youth magazines concepts such as generation next are disseminated. The complete atmosphere of metropolitan Jakarta through the mass media brought into the living rooms. The opinions and attitudes of some of the well-known young showbiz-stars make them to be youth 'role models'" (Sastramidjaja 2000: 6). In contrast to common perception, for Sastramidjaja the mass media do not 
in the first place promote a consumerist attitude, but freedom, independence, and power.

The media (mass and social media) has also been crucial in popularizing the language of anak Jakarta throughout the country. People in the periphery see Jakarta as the centre of power, wealth, and modernity. The behaviour of the people of Jakarta has become the model for others. This includes the use of the slang language commonly spoken by the youth. In order to be seen as modern, youth outside Jakarta prefer to speak bahasa Prokem or bahasa gaul or write bahasa Alay to speaking their native language or the correct Indonesian language. Local television and radio talk shows are considered "not-in" when they do not use the slang language of anak Jakarta (Swastika 2012).

\section{CONCLUSIONS}

Over several decades the youth in Jakarta, like their peers all over the world, show characteristics typical of people in that stage of life. They are spontaneous, emotional, adventurous, free, informal, rebellious, dislike rules and traditions, attention seeking, eager to try and adopt new things and technologies, status conscious, fashion minded, and consumptive. The youth search role models from what they perceive to be symbols of modern life to develop own identity. The group solidarity among the youth is strong and they maintain exclusivity by using a code language not understood by adults or other youth groups. The peer relation is very important to the youth. Peers determine the social norms and values in the youth culture. Strong group solidarity sometimes results in anti-social or delinquent behaviours such as group fights, vandalism, and cutting class.

Jakarta youth culture is a blend of various ethnic characteristics and western cultures. Ethnic identity is difficult to find in anak Jakarta. The native language (bahasa daerah) as the basic element for ethnic identity is no longer spoken. Bahasa gaul, a language developed from the Betawi dialect, and the code language of the underworld, has become the mother-tongue of anak Jakarta. More recently, the bahasa Alay is gaining popularity among the youth.

What can be observed as typical of today's anak Jakarta are: the slang language they use, their outfit, brand mindedness, and their habit to hang around shopping malls and game stations. More recent phenomena are the ABG group and tawuran (group fights). The Jakarta youth are fashion, language, and lifestyle trendsetters. Other youth copy this style and image learned from the mass and social media.

Migrant youth in Jakarta feel it is essential to adopt the style of anak Jakarta to be accepted by the local youth, to climb up the social ladder and to be able to survive in the harsh metropolitan life of Jakarta. For the youth with low purchasing power, this adjustment often leads them to debt (purchasing consumer goods on credit).

The media is the most powerful factor in the dissemination of youth culture. All information on the most recent happenings and lifestyles are brought into the living room of each household across the country and in the 
world. In this era of high technology, the youth can easily maintain contact with young people all over the world. Consequently, this advanced technology facilitates and accelerates the adoption of the anak Jakarta identity by the youth in other cities and in rural areas.

The process of developing self-identity among the youth is very strongly influenced by their peers. The youth in Jakarta can seldom resist the pressure of their peers, fearing for ridicule, humiliation and social exclusion. Meeting the demands of their peers is more important than obeying parents and teachers. How much peer pressure affects the youth depends on parental upbringing and discipline.

Parental attitude towards youth behaviour and culture differs. More traditional and middle and low-income parents are not supportive of the youth consumerism. Other parents, however, stimulate the youth to reach the highest social status and encourage consumerism.

Since youth culture keeps changing and is responsive to new development, the identity of anak Jakarta will also change over time. The portrait of anak Jakarta keeps changing as shown in this study, which is a reflection over three decades. In each period, youth in other places copied and adopted anak Jakarta identity as a prototype. Indeed the core characteristic of anak Jakarta is trendsetter for the Indonesian youth. As trendsetters, the Jakarta youth will continuously come with new styles and new languages. The youth's desire to become trendsetters has a positive effect on the country's economy: new styles and models in clothing, accessories, and gadgets are produced, following the changing world fashion. Further studies are needed to explore the changing patterns of the identity of Jakarta youth over a period of time and its importance for the economic and social development of the Indonesians.

\section{REFERENCES}

Ansori, Moh. Hasan. 2009, "Consumerism and the emergence of a new middle class in globalizing Indonesia", Exploration; A Graduate Student Journal of Southeast Asian Studies Vol. 9, Spring 2009: 87-97. [Http:/ / scholarspace. manoa.hawaii.edu/bitstream / handle/10125/10713/uhm...?sequence=1, accessed on 24-6-2013.]

Badudu, J.S. 1996. Inilah Bahasa Indonesia yang benar. Jakarta: Gramedia.

Ehrlich, Eugene et al. 1986. Oxford American Dictionary. New York: Avon. [Heald Colleges Edition.]

Gerke, Solvay. 1995. "Symbolic consumption and the Indonesian middle class". University of Bielefeld, Southeast Asia Programme, working paper n. 233.

Hannerz, U. 1996. Transnational connections; Culture, people, places. London: Routledge.

Havianty, Mira. 2012. "Bahasa gaul dalam kegalauan remaja”, MyEdustyle; Education and lifestyle, 9 November 2012. [Http://myedustyle.blogspot. nl/2012/11/bahasa-gaul-dalam-kegalauan-remaja_333.html, accessed on 26-5-2013.]

Heaven, Cara and Matthew Tubridy. 2003. “Global youth culture and youth 
identity", in James Arvanitakis (ed.), Highly affected, rarely considered; The International Youth Parliament's Commission report on the impacts of globalisation on young people, pp. 149-160. Surry Hills: International Youth Parliament (IYP); Oxfam Community Aid Abroad. [Http://www.tachbik. ma/documents/da619779-5Global\%20Youth\%20 Culture\%20and $\% 20$ Youth\%20Identity.pdf, accessed on 30-4-2013.]

Konkzmedia. 2012. "Kamus bahasa Alay terbaru". [Http://konkzmedia. blogspot.nl/ 2012/11/kamus-bahasa-alay-terbaru.html, accessed on 146-2013.]

Lapanpuluhan. 2006. "Profil anak Jakarta taon 80-an versi gue". [Http:// lapanpuluhan.blogspot. $\mathrm{nl} / 2006 / 03$ / profil-anak-jkt-taon-80-versi-gue. html, accessed on 28-4-2013.]

Leeuwen, Lizzy van. 1997. Airconditioned lifestyles; De nieuwe rijken in Jakarta. Amsterdam: Het Spinhuis.

Leeuwen, Lizzy van. 2011. Lost in mall; An ethnography of middle-class Jakarta in the 1990s. Leiden: KITLV Press.

Lumintaintang, Yayah B. Mugnisjah. 2000. "Pemilihan ragam bahasa bagi pengajaran BIPA", in: A. Chaedar Alwasilah and A. Kholid (eds), Prosiding Konperensi Internasional Pengajaran Bahasa Indonesia bagi Penutur Asing, n.p. Bandung: Andira.

Matheson Hooker, V. and H. Dick. 1993. Introduction to culture and society in New Order Indonesia. Oxford: Oxford University Press.

Rahardja, Prathama and Henri Chambert-Loir. 1990. Kamus bahasa Prokem. Jakarta: Pustaka Utama Grafiti. [Revised edition.]

Republika. 2003. “ABG, Siapakah mereka?” Republika, 7 February 2003

Sahertian, Debby. 2002. Kamus Bahasa Gaul. Jakarta: Pustaka Sinar Harapan.

Sarjana, Fasya. 2009. "Bahasa gaul; Habis prokem terbitlah alay", Bandung Linguistic Circle, 15 December 2009. [Http://linguistic-circle.blogspot. $\mathrm{nl} / 2009 / 12 /$ bahasa-gaul-habis-prokem-terbitlah-alay.html, accessed on 26-5-2013.]

Sarwono, Sarlito W. 1989. Psikologi remaja. Jakarta: Rajawali.

Sastramidjaja, Y. 2000. Dromenjagers in Bandung - twintigers in het moderne Indonesië. Amsterdam: Het Spinhuis.

Stöve, Gustaaf. 2001. "Globalization and urban lifestyles in Indonesia". University of Amsterdam. [Unpublished paper.]

Swastika, Alia. 2012. "Anak kota punya gaya", Newsletter KUNCI No 12, June. [Http:/ / farislaode.blogspot.nl/2012/01/anak-kota-punya-gaya.html, accessed on 15-6-2013.]

Tampati, Rahib. 2012. "Sejarah tawuran pelajar di Jakarta dari masa ke masa", Platform Pendidikan Indonesia. [Http://www.pendidikankarakter.org/ RedTie/sejarah-tawuran-pelajar-di-jakarta-dari-masa-ke-masa.html, accessed on 26-5-2013.]

Unnanoche. 2010. "Bahasa gaul dari waktu ke waktu”, Unnanoche's Blog, 5 July 2010. [Http:/ / unnanoche.wordpress.com/2010/07/05/ bahasa-gauldari-waktu-ke-waktu/, accessed on 26-5-2013.] 
Wikipedia. 2011. “Alay", [Http://en.wikipedia.org/wiki/Alay, accessed on 15-6-2013.]

Wisbenbae. 2010. “Trend anak gaul Jakarta tahun 90-an”. [Http:// wisbenbae. blogspot.com /2010/06/trend-anak-gaul-jakarta-tahun-90.html, accessed on 6-5-2013.]

Wittman, Leonie. 2004. "Generasi Y - Apakah ini citra anda?". Ryde: NSW Department of Education and Training. [Unpublished paper.]

Yahoo mail group. 2010. "Profil anak Jakarta taon 80-an". [Http:/ / tech.groups. yahoo.com / group/sekongberry/message/66632, accessed on 28-5-2013.]

Zander, Diki Zulkarnaen. 2012. "Tawuran pelajar memprihatinkan dunia pendidikan", Platform Pendidikan Indonesia. [Http://www.pendidikankarakter. org/RedTie/tawuranpelajarmemprihatinkanduniapendidikan.html, accessed on 26-5-2013.] 